\title{
Erratum to: Phenotypic Integration Without Modularity: Testing Hypotheses About the Distribution of Pleiotropic Quantitative Trait Loci in a Continuous Space
}

\author{
Charles C. Roseman · Jane P. Kenney-Hunt •
}

James M. Cheverud

Published online: 4 November 2009

(C) Springer Science+Business Media, LLC 2009

Erratum to: Evol Biol (2009) 36:282-291

DOI 10.1007/s11692-009-9067-6

The second author's name was misspelled. The correct spelling of her name is Jane P. Kenney-Hunt.

The online version of the original article can be found under doi:10.1007/s11692-009-9067-6.

\section{C. Roseman ( $\varangle)$}

Department of Anthropology, University of Illinois,

Urbana-Champaign, 109A Davenport Hall, 607 S. Mathews Ave,

Urbana, IL 61802, USA

e-mail: croseman@uiuc.edu

\section{J. P. Kenney-Hunt}

Department of Biological Sciences, University of South

Carolina, Columbia, SC 29208, USA

J. M. Cheverud

Department of Anatomy and Neurobiology, Washington

University School of Medicine, St. Louis, MO 63110, USA 